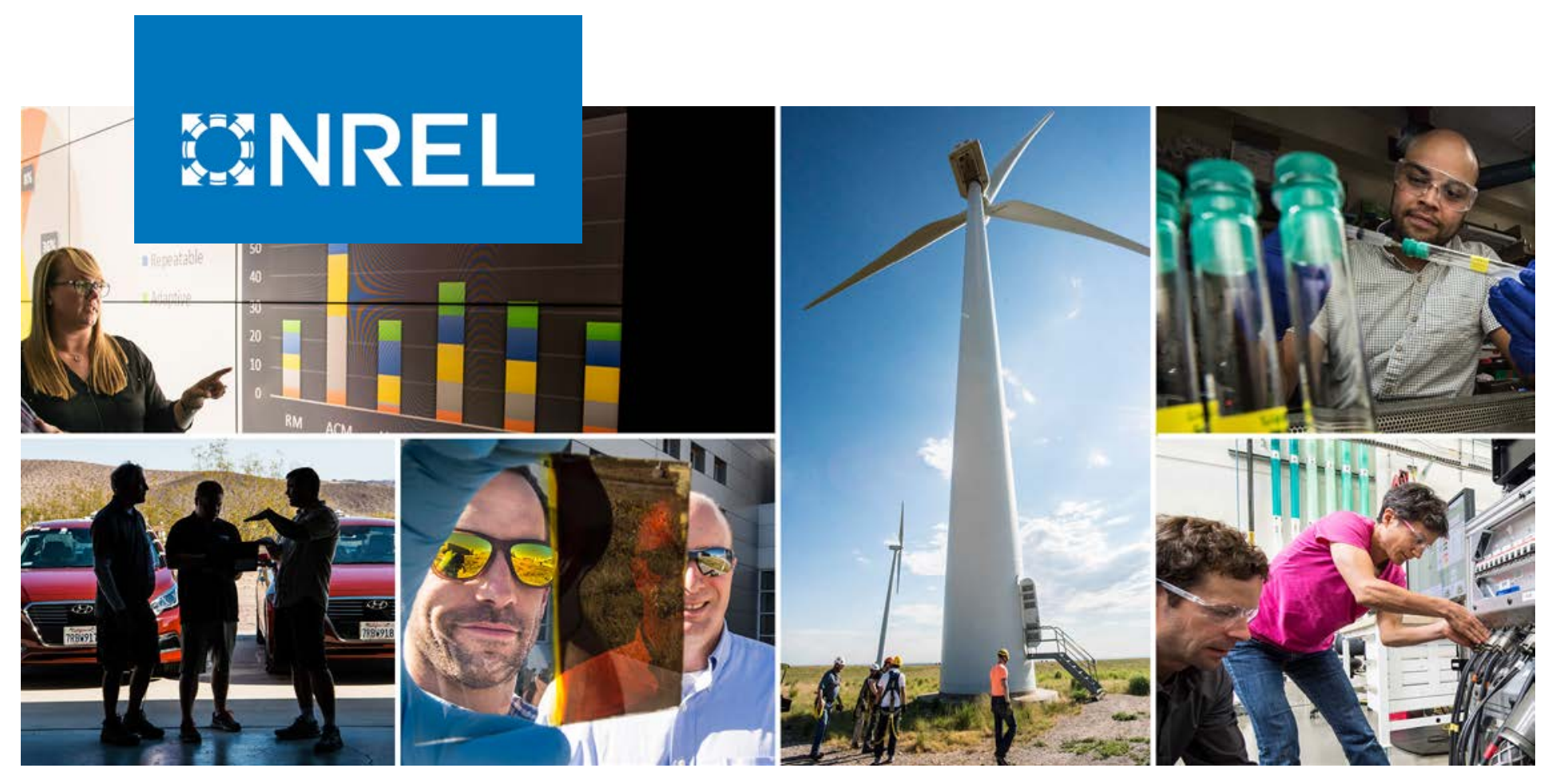

\title{
Assessment of BQ-9000 Biodiesel Properties for 2019
}

Teresa L. Alleman

National Renewable Energy Laboratory

NREL is a national laboratory of the U.S. Department of Energy

Office of Energy Efficiency \& Renewable Energy

Operated by the Alliance for Sustainable Energy, LLC

This report is available at no cost from the National Renewable Energy Laboratory (NREL) at www.nrel.gov/publications.

\section{Technical Report}

NREL/TP-5400-76840

August 2020 


\title{
GNREL
}

\section{Assessment of BQ-9000 Biodiesel Properties for 2019}

\author{
Teresa L. Alleman
}

National Renewable Energy Laboratory

\section{Suggested Citation}

Alleman, Teresa. 2020. Assessment of BQ-9000 Biodiesel Properties for 2019. Golden, CO: National Renewable Energy Laboratory. NREL/TP-5400-76840.

https://www.nrel.gov/docs/fy20osti/76840.pdf.

NREL is a national laboratory of the U.S. Department of Energy Office of Energy Efficiency \& Renewable Energy Operated by the Alliance for Sustainable Energy, LLC

This report is available at no cost from the National Renewable Energy Laboratory (NREL) at www.nrel.gov/publications.

Contract No. DE-AC36-08GO28308
Technical Report NREL/TP-5400-76840 August 2020

National Renewable Energy Laboratory 15013 Denver West Parkway Golden, CO 80401 303-275-3000 • www.nrel.gov 


\section{NOTICE}

This work was authored by the National Renewable Energy Laboratory, operated by Alliance for Sustainable Energy, LLC, for the U.S. Department of Energy (DOE) under Contract No. DE-AC36-08GO28308. Funding provided by the National Biodiesel Board. The views expressed herein do not necessarily represent the views of the DOE or the U.S. Government.

This report is available at no cost from the National Renewable Energy Laboratory (NREL) at www.nrel.gov/publications.

U.S. Department of Energy (DOE) reports produced after 1991 and a growing number of pre-1991 documents are available free via www.OSTI.gov.

Cover Photos by Dennis Schroeder: (clockwise, left to right) NREL 51934, NREL 45897, NREL 42160, NREL 45891, NREL 48097, NREL 46526.

NREL prints on paper that contains recycled content. 


\section{Acknowledgments}

Funding support for this work was provided by the National Biodiesel Board under Cooperative Research and Development Agreement CRD-15-593. The author wishes to thank Mr. Steve Howell of M4 Consulting, Mr. Scott Fenwick of the National Biodiesel Board, and Dr. Richard Nelson of Enersol Resources for technical support for this work. 


\section{List of Acronyms}

ASTM

B100

CSFT

NREL
ASTM International

neat ( $100 \%$ by volume) biodiesel

cold soak filterability test

National Renewable Energy Laboratory 


\section{Executive Summary}

This is the third report in the series documenting the annual quality of neat biodiesel (B100) produced and sold in the United States and Canada in calendar year 2019. The data only includes companies that participate in the industry's voluntary quality program, BQ-9000. Each company that agreed to provide monthly data did so voluntarily to a third-party group. This third-party group of industry experts removed any identifying information and randomized the data prior to providing the data to the National Renewable Energy Laboratory (NREL) for statistical analysis. The quality parameters covered in this report are: sodium and potassium $(\mathrm{Na}+\mathrm{K})$; calcium and magnesium $(\mathrm{Ca}+\mathrm{Mg})$; phosphorus $(\mathrm{P})$; flash point or alcohol control; water and sediment; cloud point; acid number; free and total glycerin; monoglycerides; sulfur; oxidation stability; visual appearance, and cold soak filterability test (CSFT). The results are summarized in Table ES-1. 
Table ES-1. BQ-9000 Critical Parameter Summary Table, Calendar Year 2019

\begin{tabular}{|c|c|c|c|c|c|c|c|}
\hline $\begin{array}{l}\text { BQ-9000 } \\
\text { Parameter }\end{array}$ & $\begin{array}{c}\text { \# of } \\
\text { Values } \\
\text { Reported }\end{array}$ & Minimum & Maximum & Average & Median & $\begin{array}{l}\text { Standard } \\
\text { Deviation }\end{array}$ & $\begin{array}{c}95^{\text {th }} \\
\text { Percentile }\end{array}$ \\
\hline $\mathrm{Na}+\mathrm{K}, \mathrm{ppm}$ & 383 & 0 & 5 & 0.588 & 0.260 & 0.857 & 2.423 \\
\hline $\mathrm{Ca}+\mathrm{Mg}, \mathrm{ppm}$ & 381 & 0 & 3.397 & 0.206 & 0.047 & 0.437 & 1.069 \\
\hline $\mathrm{P}, \mathrm{ppm}$ & 361 & 0 & 10 & 0.465 & 0 & 1.593 & 3.000 \\
\hline Flash Point, ${ }^{\circ} \mathrm{C}$ & 479 & 95 & 200 & 152 & 157 & 25 & $105^{a}$ \\
\hline $\begin{array}{c}\text { Alcohol Control, } \\
\text { mass } \%\end{array}$ & 197 & 0 & 0.200 & 0.072 & 0.070 & 0.048 & 0.140 \\
\hline $\begin{array}{c}\text { Water and } \\
\text { Sediment, vol\% }\end{array}$ & 295 & 0 & 0.025 & 0.002 & 0 & 0.004 & 0.010 \\
\hline Cloud Point, ${ }^{\circ} \mathrm{C}$ & 523 & -6.0 & 15.8 & 0.956 & 0 & 3.848 & 10 \\
\hline $\begin{array}{l}\text { Acid Number, } \\
\mathrm{mg} \mathrm{KOH/g}\end{array}$ & 521 & 0.070 & 0.490 & 0.266 & 0.270 & 0.103 & 0.431 \\
\hline $\begin{array}{l}\text { Free Glycerin, } \\
\text { mass } \%\end{array}$ & 490 & 0 & 0.020 & 0.005 & 0.005 & 0.004 & 0.013 \\
\hline $\begin{array}{l}\text { Total Glycerin, } \\
\text { mass } \%\end{array}$ & 523 & 0 & 0.228 & 0.094 & 0.101 & 0.045 & 0.171 \\
\hline $\begin{array}{c}\text { Monoglycerides, } \\
\text { mass } \%\end{array}$ & 511 & 0.008 & 0.666 & 0.269 & 0.309 & 0.123 & 0.418 \\
\hline Sulfur, ppm & 501 & 0 & 15 & 4.081 & 2.800 & 3.938 & 11.800 \\
\hline $\begin{array}{l}\text { Oxidation } \\
\text { Stability, hr. }\end{array}$ & 523 & 3.800 & 24.200 & 9.107 & 8.446 & 2.930 & $5.3^{a}$ \\
\hline $\begin{array}{c}\text { Cold Soak } \\
\text { Filterability Test, } \\
\text { sec }\end{array}$ & 523 & 61 & 330 & 101 & 95 & 25 & 153 \\
\hline
\end{tabular}




\section{Table of Contents}

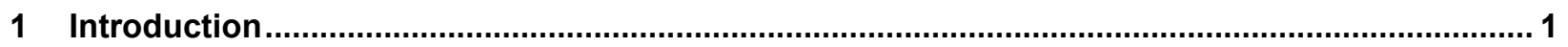

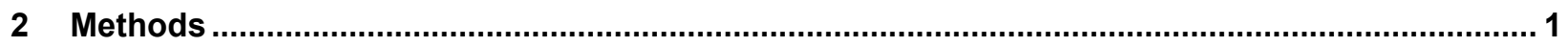

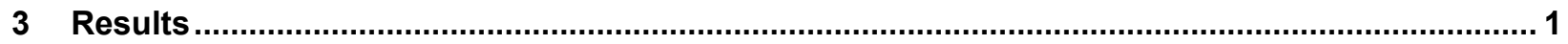

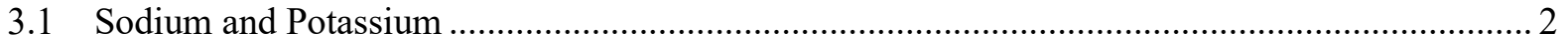

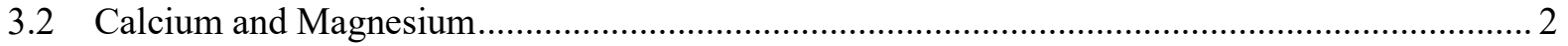

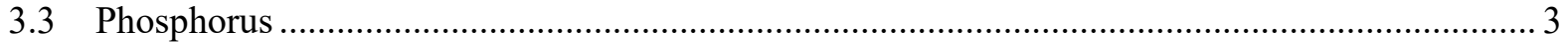

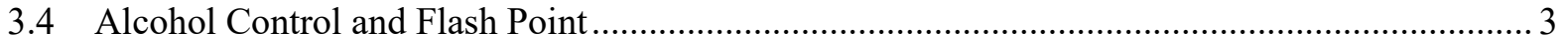

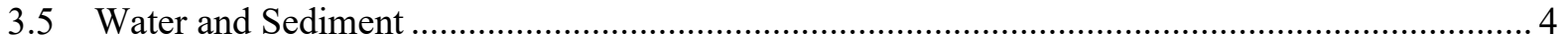

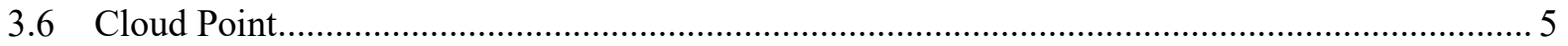

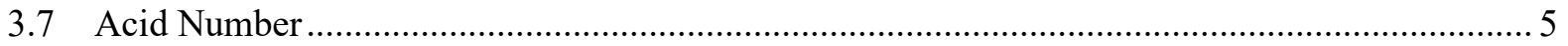

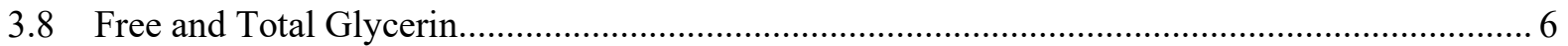

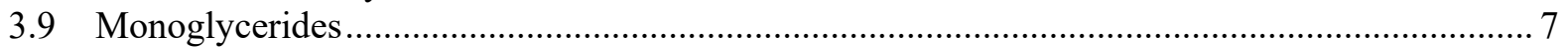

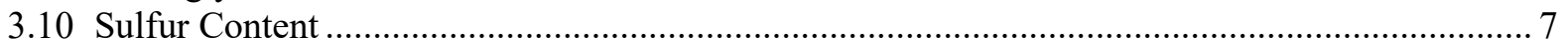

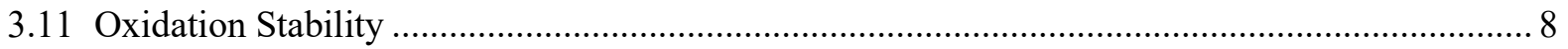

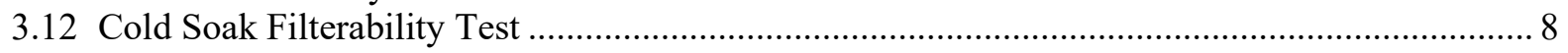

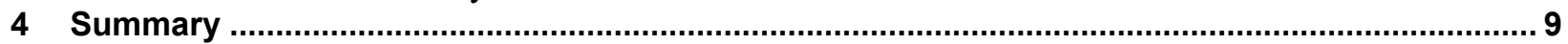

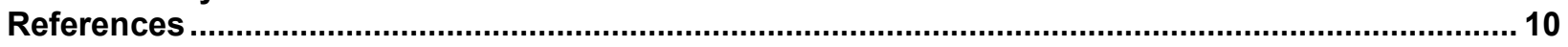

Appendix 


\section{List of Figures}

Figure 1. Sodium and potassium content for biodiesel samples produced January-December 2019.......... 2

Figure 2. Calcium and magnesium content for biodiesel samples produced January-December 2019 ....... 2

Figure 3. Phosphorus content for biodiesel samples produced January-December 2019 ......................... 3

Figure 4. Flash point for biodiesel samples produced in 2019, January-December 2019 ......................... 3

Figure 5. Methanol content for biodiesel samples produced in 2019, January-December 2019................. 4

Figure 6. Water and sediment for biodiesel samples produced in 2019, January-December 2019............. 4

Figure 7. Cloud point for biodiesel samples produced in 2019, January-December 2019........................5

Figure 8. Acid number for biodiesel samples produced in 2019, January-December 2019 ...................... 5

Figure 9. Free glycerin content for biodiesel samples produced in 2019, January-December 2019........... 6

Figure 10. Total glycerin content for biodiesel samples produced in 2019, January-December 2019 ........ 6

Figure 11. Monoglyceride content for biodiesel samples produced in 2019, January-December 2019...... 7

Figure 12. Sulfur content biodiesel samples produced in 2019, January-December 2019...................... 7

Figure 13. Oxidation stability for biodiesel samples produced in 2019, January-December 2019............. 8

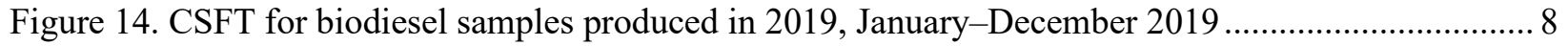

Figure A-1. All data analysis of sodium and potassium content for neat ( $100 \%$ by volume) biodiesel

(B100) samples produced January-December 2019 ......................................................... 11

Figure A-2. All data analysis of calcium and magnesium content for B100 samples produced January-

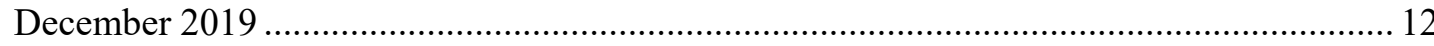

Figure A-3. All data analysis of phosphorus content for B100 samples produced January-December 2019

Figure A-4. All data analysis of flash point for B100 samples produced Janua

Figure A-5. All data analysis of alcohol control for B100 samples produced January-December

Figure A-6. All data analysis of water and sediment for B100 samples produced January-December 2019

(n)

Figure A-7. All data analysis of cloud point for B100 samples produced January-December $2019 \ldots \ldots \ldots 14$

Figure A-8. All data analysis of acid number for B100 samples produced January-December 2019 ....... 15

Figure A-9. All data analysis of free glycerin content for B100 samples produced January-December

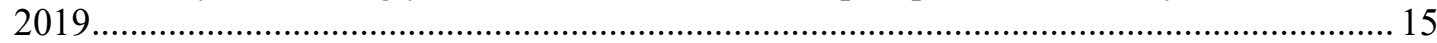

Figure A-10. All data analysis of total glycerin content for B100 samples produced January-December 2019

Figure A-11. All data analysis of monoglyceride content for B100 samples produced January-December 2019.

Figure A-12. All data analysis of sulfur content for B100 samples produced January-December 2019 ... 17

Figure A-13. All data analysis of oxidation stability for B100 samples produced January-December 2019

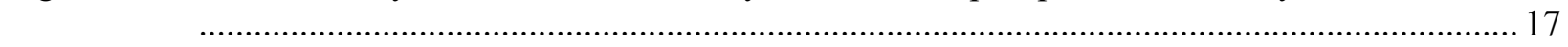

Figure A-14. All data analysis of CSFT for B100 samples produced January-December 2019.............. 18

\section{List of Tables}

Table ES-1. BQ-9000 Critical Parameter Summary Table, Calendar Year 2019 .....................................vi

Table 1. BQ-9000 Critical Parameter Summary Table, Calendar Year 2019 ........................................ 9 


\section{Introduction}

The National Renewable Energy Laboratory (NREL) has a long collaboration with the biodiesel industry and has leveraged this relationship to acquire data for this report. This report, the third in an ongoing series, summarizes the quality of biodiesel produced and sold in the United States and Canada. This report covers calendar year 2019, with previous reports for 2017 and 2018 (Alleman 2020a; Alleman 2020b). The analysis was limited to producers that participate in the voluntary biodiesel industry quality program, BQ-9000. ${ }^{1}$

The BQ-9000 program requires analysis of many critical fuel quality parameters: sodium and potassium $(\mathrm{Na}+\mathrm{K})$, calcium and magnesium $(\mathrm{Ca}+\mathrm{Mg})$, phosphorus $(\mathrm{P})$, flash point or alcohol control, water and sediment, cloud point, acid number, free and total glycerin, monoglycerides, sulfur (S), oxidation stability, visual appearance, and cold soak filterability test (CSFT). This report covers 6,211 individual data points for calendar year 2019.

\section{Methods}

Similar to previous reports, Mr. Scott Fenwick of the National Biodiesel Board, Mr. Steve Howell of M4 Consulting, and Dr. Richard Nelson of Enersol Resources contacted participants in the BQ-9000 program and requested their monthly fuel quality data. Fuel quality data were provided voluntarily to this third-party team for calendar year 2019.

The data set was anonymized by removing identifying information such as company name, location, and production lot. To further ensure confidentiality of participants, each parameter was independently randomized, and the resulting "clean" data set provided to NREL for statistical analysis. The analysis included minimum and maximum, average and median, standard deviation, and $95^{\text {th }}$ percentile. The $5^{\text {th }}$ percentile was reported for flash point and oxidation stability.

The participating producers were asked to provide data "as-is," which meant that data fell into two categories (similar to previous years): actual values, or values provided as "greater than" or "less than." In the case where actual values were provided by the producer, these values were used in the analysis. Data reported as "greater than" and "less than" were removed from the data set presented in the body of the report. For example, a flash point reported as $>130^{\circ} \mathrm{C}$ was removed from the main body of the report but was included in the Appendix and assumed to have a flash point of $130^{\circ} \mathrm{C}$.

\section{Results}

The property limitations for biodiesel are set in ASTM International (ASTM) D6751, Standard Specification for Biodiesel Fuel Blend Stock (B100) for Middle Distillate Fuels (ASTM 2020). ASTM D6751 also lists applicable test methods and discusses the significance of the test parameters.

\footnotetext{
${ }^{1}$ Additional discussion of the BQ-9000 program is available at bq-9000.org and in Alleman 2020a.
} 
Following are the results from analysis of the 2019 data set by critical parameter.

\subsection{Sodium and Potassium}

$\mathrm{Na}+\mathrm{K}$ averaged 0.6 parts per million (ppm) for 2019 (Figure 1). The $95^{\text {th }}$ percentile was 2.42 ppm and the median was $0.26 \mathrm{ppm}$.

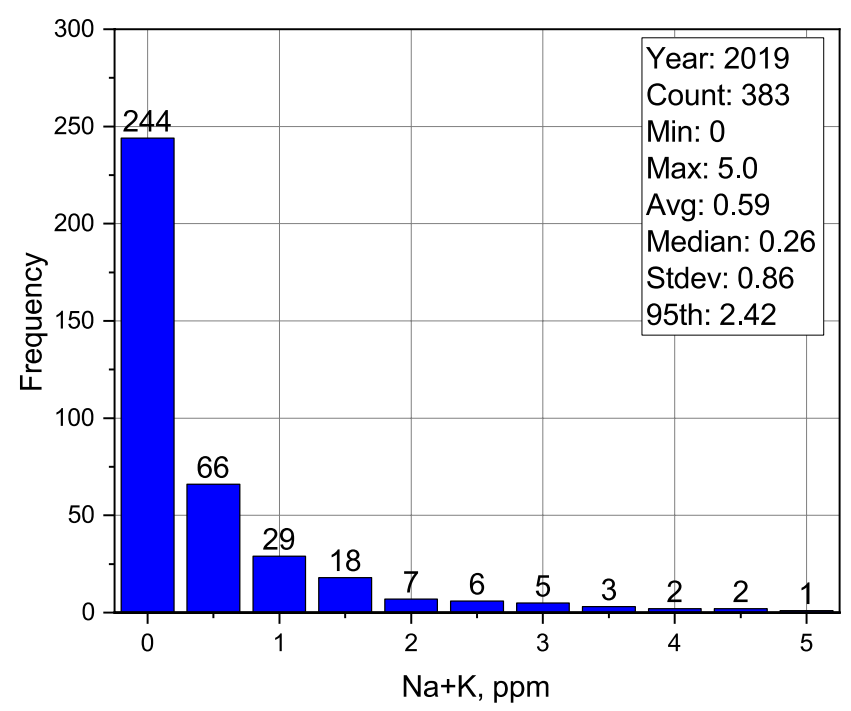

Figure 1. Sodium and potassium content for biodiesel samples produced January-December 2019

\subsection{Calcium and Magnesium}

The average $\mathrm{Ca}+\mathrm{Mg}$ for biodiesel produced in 2019 was $0.21 \mathrm{ppm}$ and the median was 0.05 ppm, as shown in Figure 2. The $95^{\text {th }}$ percentile of the data was $1.10 \mathrm{ppm}$.

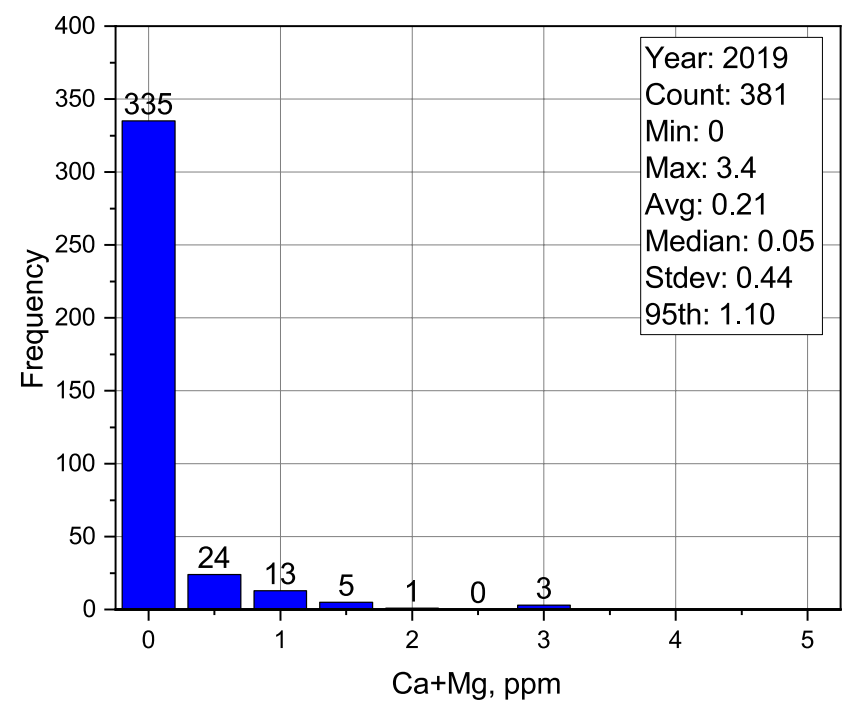

Figure 2. Calcium and magnesium content for biodiesel samples produced January-December 2019 


\subsection{Phosphorus}

Figure 3 illustrates the $\mathrm{P}$ content, with an average of $0.46 \mathrm{ppm}$. The median $\mathrm{P}$ content was $0 \mathrm{ppm}$ and the $95^{\text {th }}$ percentile was $3.00 \mathrm{ppm}$.

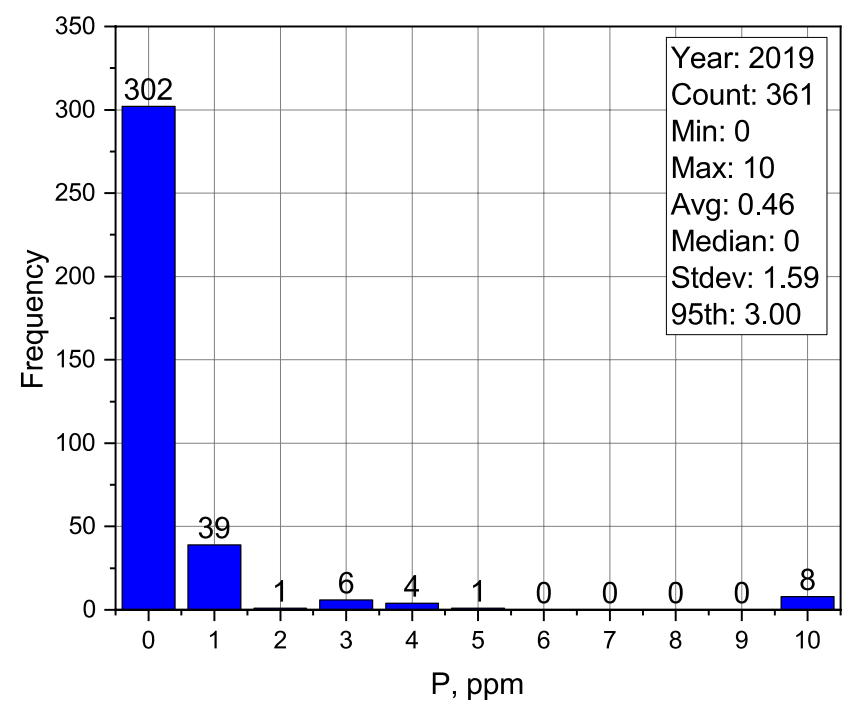

Figure 3. Phosphorus content for biodiesel samples produced January-December 2019

\subsection{Alcohol Control and Flash Point}

The average flash point of the 2019 biodiesel samples was $152^{\circ} \mathrm{C}$, with a median of $157^{\circ} \mathrm{C}$. The $5^{\text {th }}$ percentile was $105^{\circ} \mathrm{C}$ (Figure 4). The average and median methanol content (Figure 5) was 0.072 mass $\%$, the median was 0.070 mass $\%$, and the $95^{\text {th }}$ percentile was 0.14 mass $\%$.

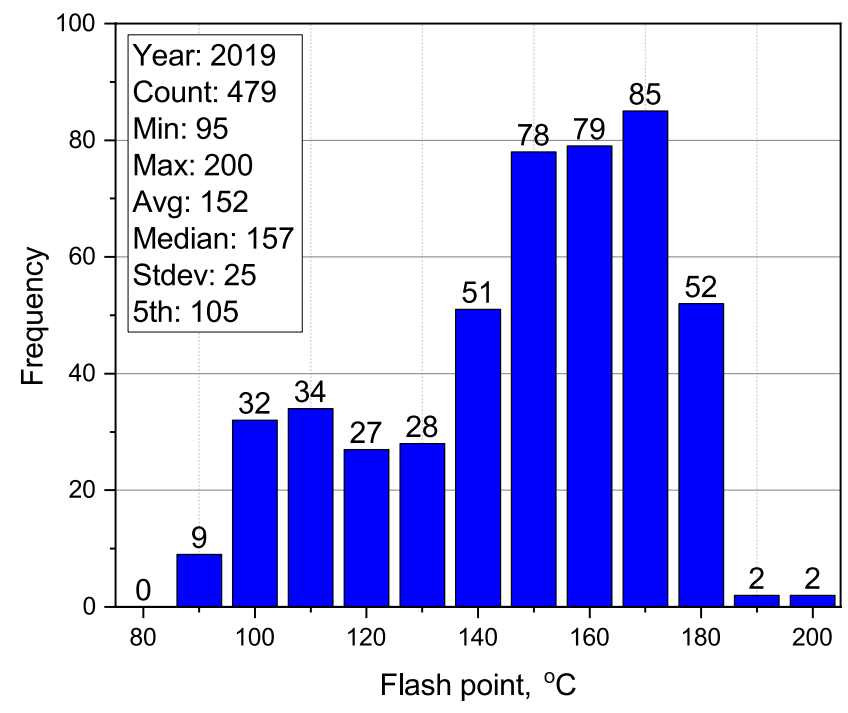

Figure 4. Flash point for biodiesel samples produced January-December 2019 


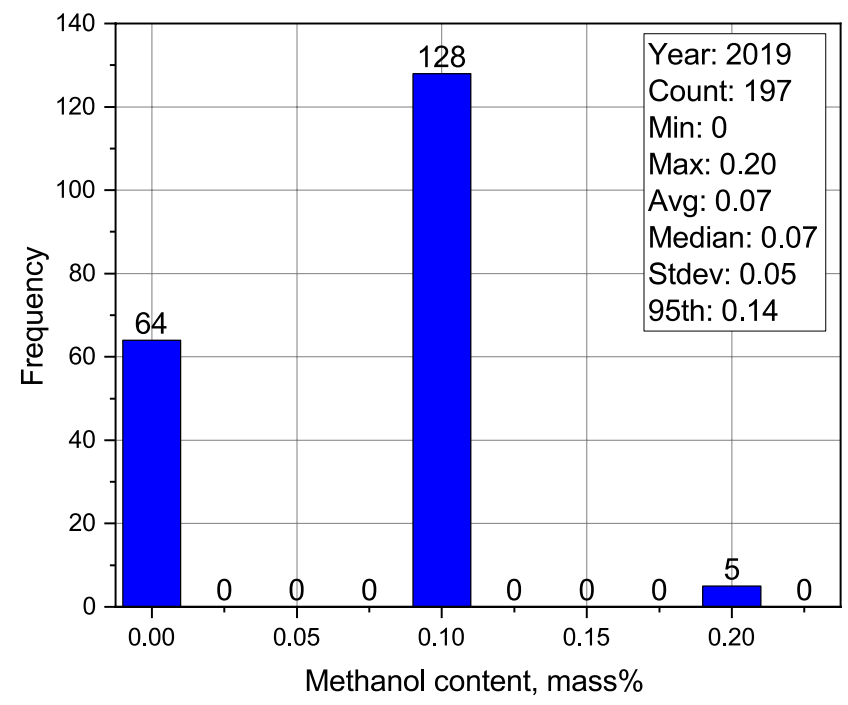

Figure 5. Methanol content for biodiesel samples produced January-December 2019

\subsection{Water and Sediment}

Figure 6 shows the water and sediment content, with an average of $0.002 \mathrm{vol} \%$. The median was 0 vol $\%$ and the $95^{\text {th }}$ percentile was 0.010 vol\%. All producers reported samples as clear and bright.

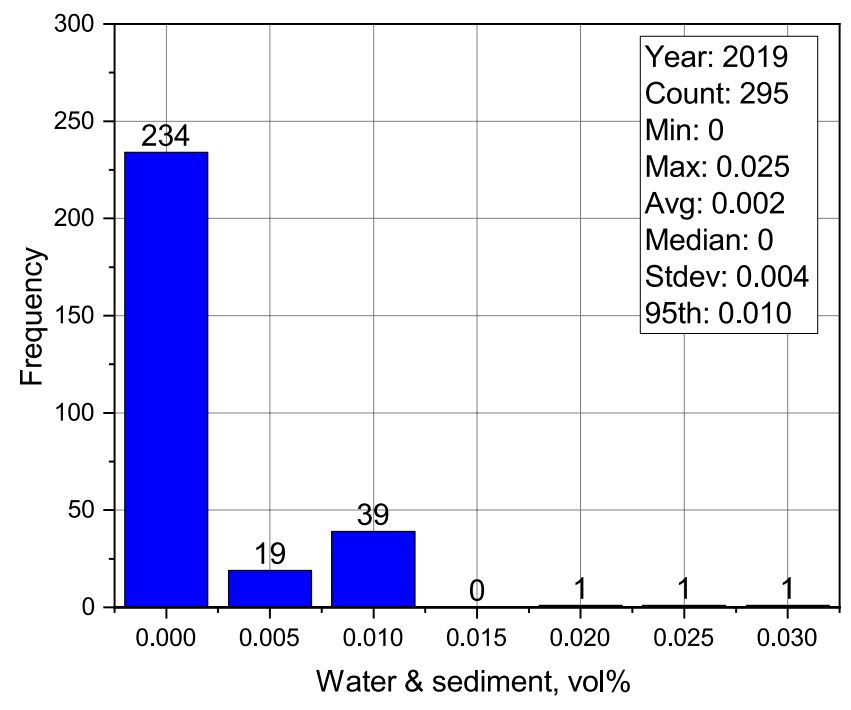

Figure 6. Water and sediment for biodiesel samples produced January-December 2019 


\subsection{Cloud Point}

The average cloud point for the 2019 samples was $0.96^{\circ} \mathrm{C}$, with a median of $0^{\circ} \mathrm{C}$ (Figure 7). The $95^{\text {th }}$ percentile was $10^{\circ} \mathrm{C}$. The cloud point is a "report value" and does not have a set minimum.

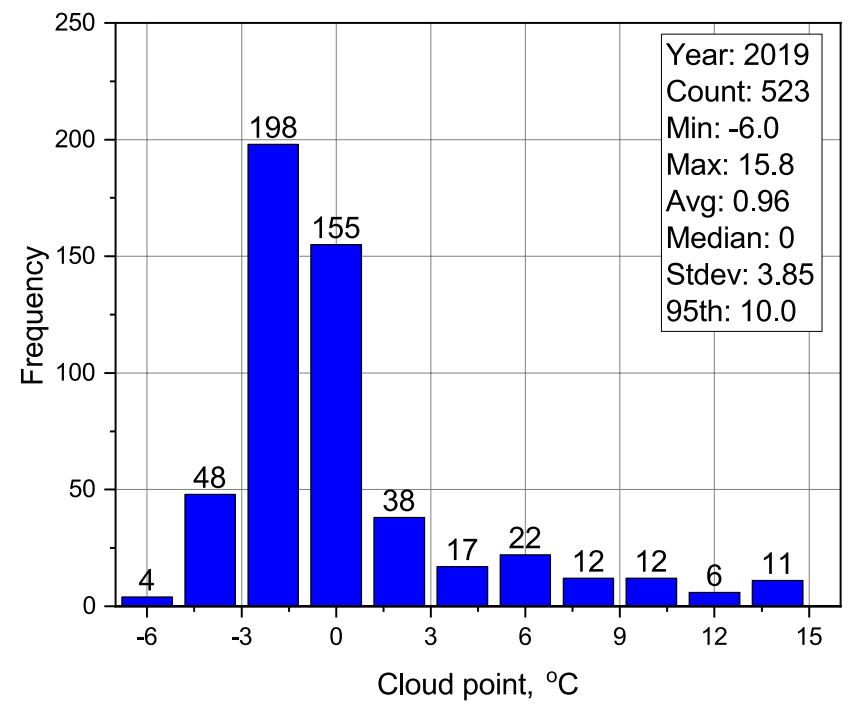

Figure 7. Cloud point for biodiesel samples produced January-December 2019

\subsection{Acid Number}

Figure 8 illustrates an average acid number of 0.27 milligrams potassium hydroxide per gram ( $\mathrm{mg} \mathrm{KOH} / \mathrm{g}$ ). The median acid number was also $0.27 \mathrm{mg} \mathrm{KOH} / \mathrm{g}$ and the $95^{\text {th }}$ percentile was 0.43 $\mathrm{mg} \mathrm{KOH} / \mathrm{g}$.

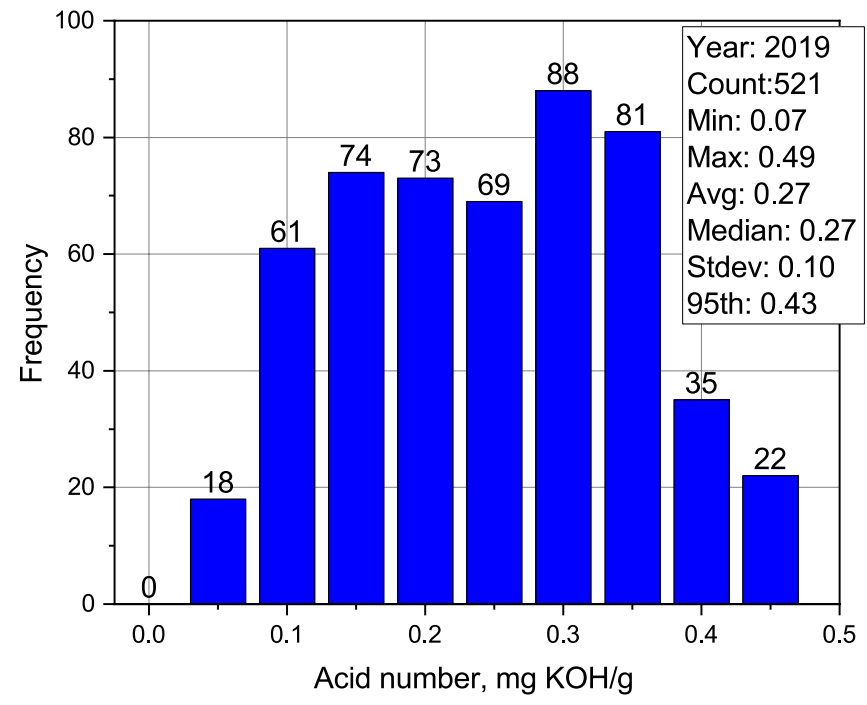

Figure 8. Acid number for biodiesel samples produced January-December 2019 


\subsection{Free and Total Glycerin}

Free glycerin, shown in Figure 9, had an average 0.005 mass $\%$, a median of 0.005 mass $\%$, and a $95^{\text {th }}$ percentile of 0.013 mass $\%$. The total glycerin, shown in Figure 10, had an average 0.094 mass $\%$. The median was 0.101 mass $\%$ and the $95^{\text {th }}$ percentile was 0.171 mass $\%$.

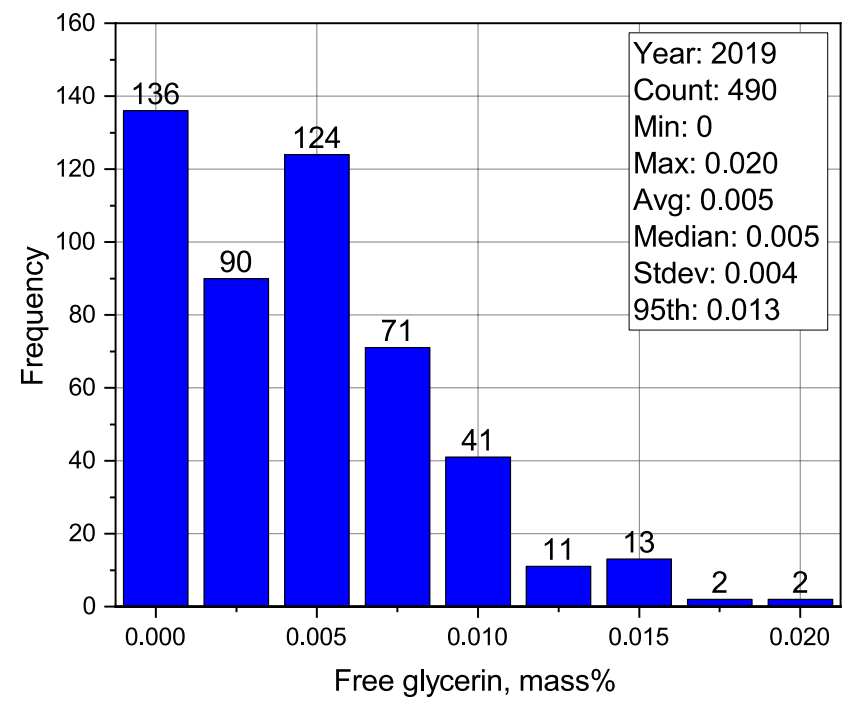

Figure 9. Free glycerin content for biodiesel samples produced January-December 2019

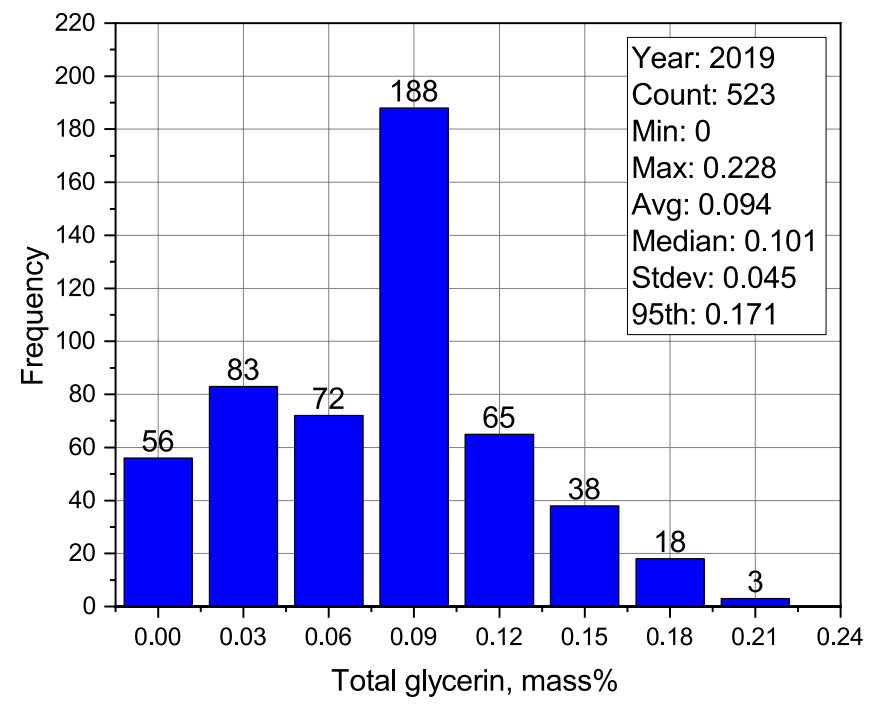

Figure 10. Total glycerin content for biodiesel samples produced January-December 2019 


\subsection{Monoglycerides}

The average monoglyceride content in 2019, illustrated in Figure 11, was 0.269 mass $\%$. The median was 0.309 mass $\%$ and the $95^{\text {th }}$ percentile was 0.418 mass $\%$.

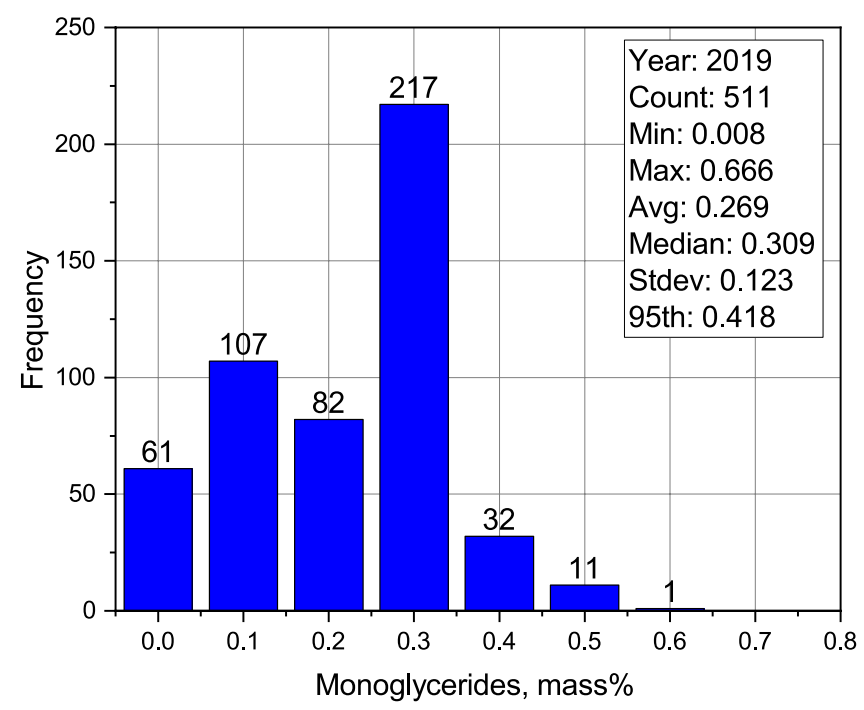

Figure 11. Monoglyceride content for biodiesel samples produced January-December 2019

\subsection{Sulfur Content}

Sulfur content of the biodiesel samples in 2019 averaged $4.1 \mathrm{ppm}$, with a median of $2.8 \mathrm{ppm}$ and a $95^{\text {th }}$ percentile of $11.8 \mathrm{ppm}$ (Figure 12).

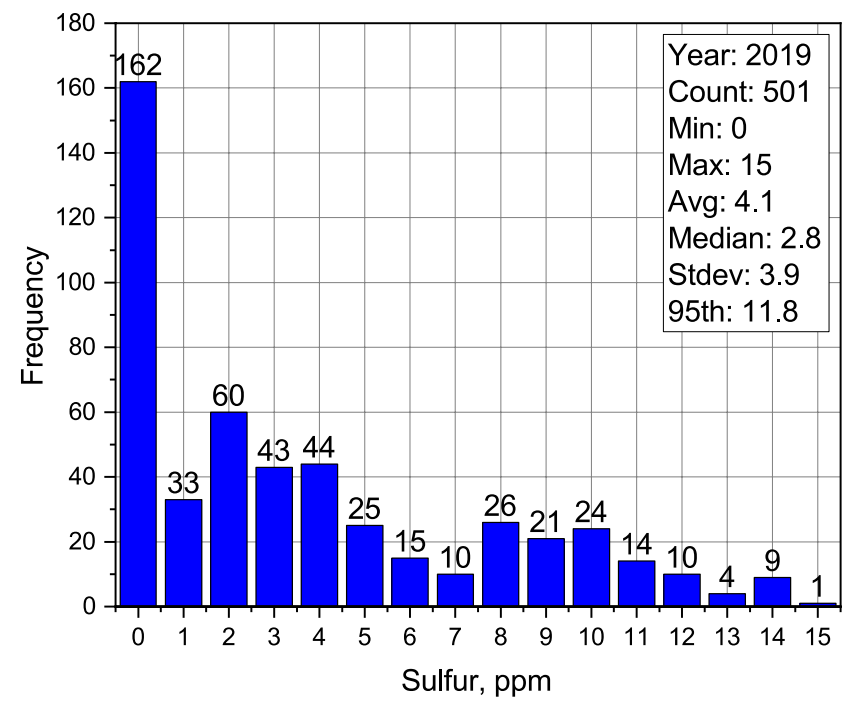

Figure 12. Sulfur content biodiesel samples produced January-December 2019 


\subsection{Oxidation Stability}

The average oxidation stability of biodiesel samples in 2019 was 9.1 hours (Figure 13). The median was 8.5 hours and the $5^{\text {th }}$ percentile was 5.3 hours.

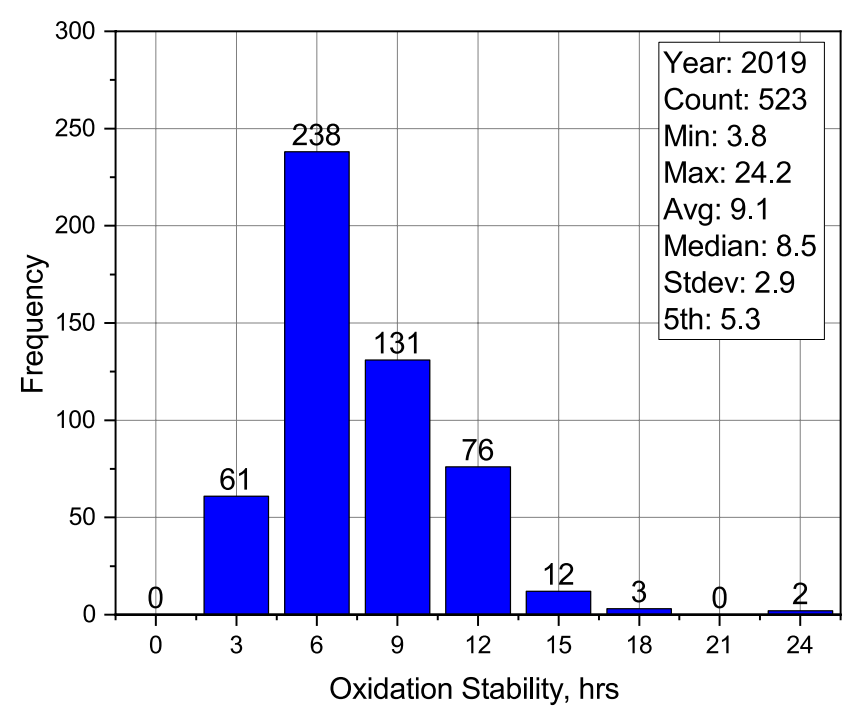

Figure 13. Oxidation stability for biodiesel samples produced January-December 2019

\subsection{Cold Soak Filterability Test}

Figure 14 shows the CSFT results from biodiesel produced in 2019. The average was 101 seconds, the median was 95 seconds, and the $95^{\text {th }}$ percentile was 153 seconds.

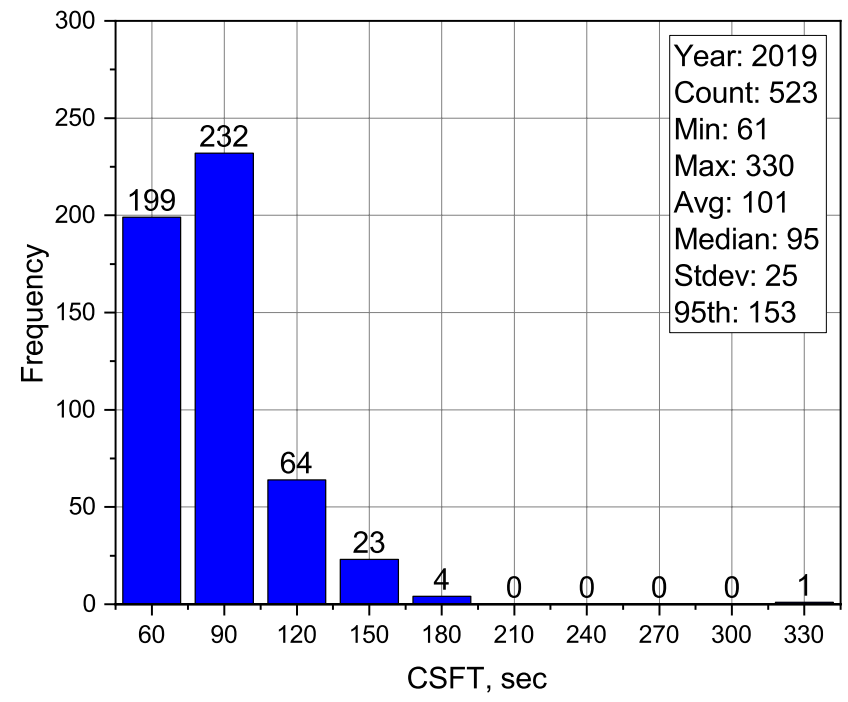

Figure 14. CSFT for biodiesel samples produced January-December 2019 


\section{Summary}

Using industry-provided data, we analyzed monthly quality parameters of biodiesel produced and sold in the United States in calendar year 2019. The data were collected by a third-party team and anonymized and randomized prior to providing to NREL. All study participants provided data voluntarily and no identifying information on participants is available.

Similar to our previous reports (Alleman 2020a and 2020b), the analysis includes parameters critical to biodiesel quality and summarized in Table 1 . The analysis shows biodiesel routinely met and exceeded the property limitations set forth in ASTM D6751 for biodiesel quality.

Table 1. BQ-9000 Critical Parameter Summary Table, Calendar Year 2019

\begin{tabular}{|c|c|c|c|c|c|}
\hline $\begin{array}{l}\text { BQ-9000 } \\
\text { Parameter }\end{array}$ & Minimum & Maximum & Average & Median & $\begin{array}{c}95^{\text {th }} \\
\text { Percentile }\end{array}$ \\
\hline $\mathrm{Na}+\mathrm{K}, \mathrm{ppm}$ & 0 & 5 & 0.588 & 0.260 & 2.423 \\
\hline $\mathrm{Ca}+\mathrm{Mg}, \mathrm{ppm}$ & 0 & 3.397 & 0.206 & 0.047 & 1.069 \\
\hline $\mathrm{P}, \mathrm{ppm}$ & 0 & 10 & 0.465 & 0 & 3.000 \\
\hline Flash Point, ${ }^{\circ} \mathrm{C}$ & 95 & 200 & 152 & 157 & $105^{a}$ \\
\hline $\begin{array}{c}\text { Alcohol Control, } \\
\text { mass } \%\end{array}$ & 0 & 0.200 & 0.072 & 0.070 & 0.140 \\
\hline $\begin{array}{c}\text { Water and } \\
\text { Sediment, vol\% }\end{array}$ & 0 & 0.025 & 0.002 & 0 & 0.010 \\
\hline Cloud Point, ${ }^{\circ} \mathrm{C}$ & -6.0 & 15.8 & 0.956 & 0 & 10 \\
\hline $\begin{array}{c}\text { Acid Number, } \\
\mathrm{mg} \mathrm{KOH/g}\end{array}$ & 0.070 & 0.490 & 0.266 & 0.270 & 0.431 \\
\hline $\begin{array}{l}\text { Free Glycerin, } \\
\text { mass } \%\end{array}$ & 0 & 0.020 & 0.005 & 0.005 & 0.013 \\
\hline $\begin{array}{l}\text { Total Glycerin, } \\
\text { mass } \%\end{array}$ & 0 & 0.228 & 0.094 & 0.101 & 0.171 \\
\hline $\begin{array}{c}\text { Monoglycerides, } \\
\text { mass } \%\end{array}$ & 0.008 & 0.666 & 0.269 & 0.309 & 0.418 \\
\hline Sulfur, ppm & 0 & 15 & 4.081 & 2.800 & 11.800 \\
\hline $\begin{array}{l}\text { Oxidation } \\
\text { Stability, hr. }\end{array}$ & 3.800 & 24.200 & 9.107 & 8.446 & $5.3^{a}$ \\
\hline $\begin{array}{c}\text { Cold Soak } \\
\text { Filterability Test, } \\
\text { sec }\end{array}$ & 61 & 330 & 101 & 95 & 153 \\
\hline
\end{tabular}

a: Data is for $5^{\text {th }}$ percentile 


\section{References}

Alleman, T.L. 2020a. Assessment of BQ-9000 Biodiesel Properties for 2017. Golden, CO: National Renewable Energy Laboratory. NREL/TP-5400-75795.

Alleman, T.L. 2020b. Assessment of BQ-9000 Biodiesel Properties for 2018. Golden, CO: National Renewable Energy Laboratory. NREL/TP-5400-75796.

ASTM International. 2020. ASTM D6751, Standard Specification for Biodiesel Fuel Blend Stock (B100) for Middle Distillate Fuels. West Conshohocken, PA: ASTM International. http://doi.org/10.1520/D6751-20. 


\section{Appendix}

The figures included in the Appendix are for informational purposes only and include all data voluntarily submitted by producers participating in the BQ-9000 program in 2019. The data shown here assumes that any data point reported as "greater than" or "less than" was simply the value reported. For example, a reported $\mathrm{Na}+\mathrm{K}$ of $<1 \mathrm{ppm}$ was assumed to be $1 \mathrm{ppm}$ for this analysis. No statistics have been calculated on the data set due to this unique method of data handling.

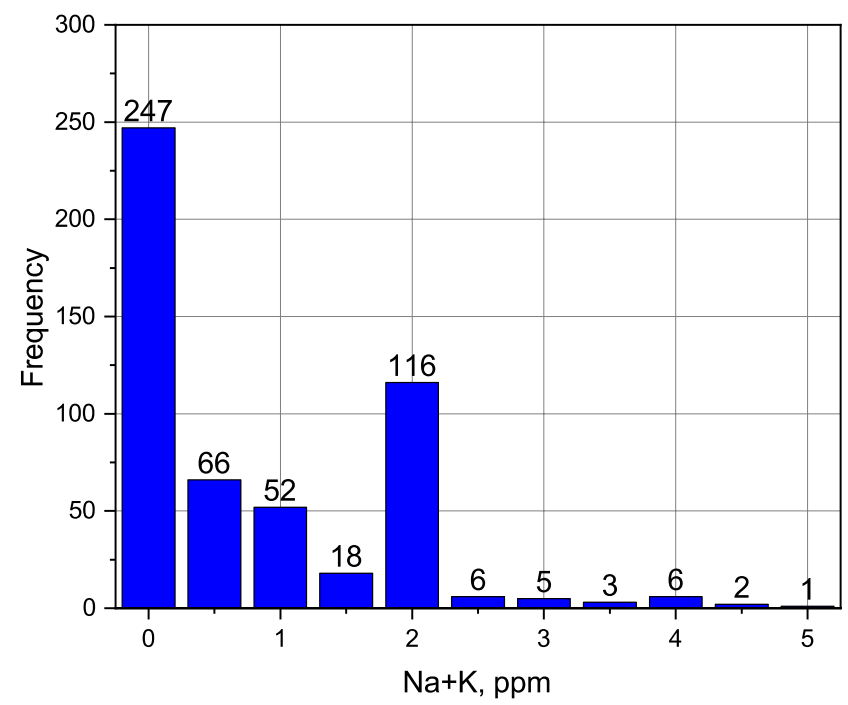

Figure A-1. All data analysis of sodium and potassium content for neat ( $100 \%$ by volume) biodiesel (B100) samples produced January-December 2019

Data reported as "greater than X" or "less than X" are assumed to have a value of X 


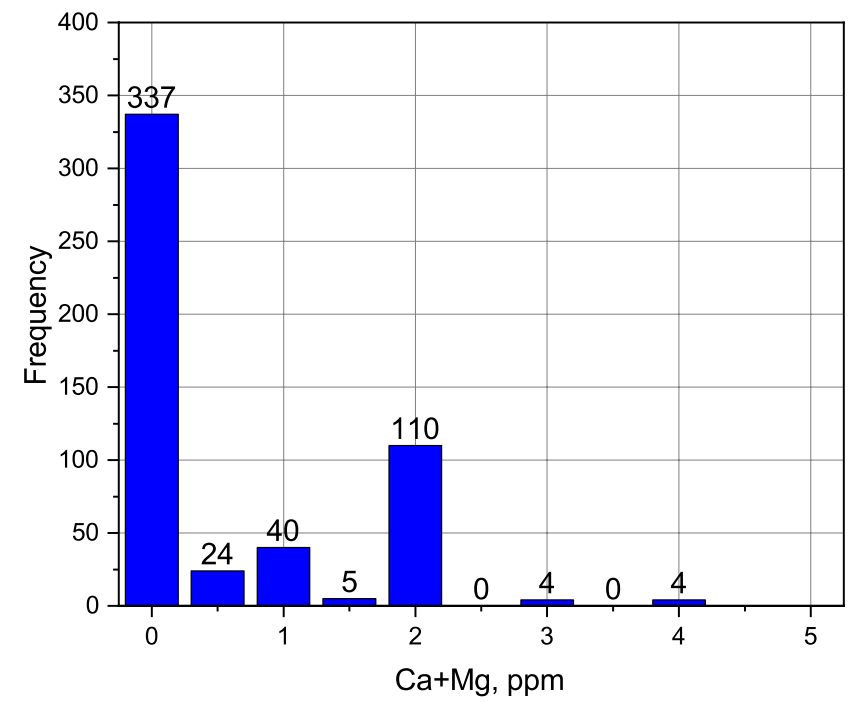

Figure A-2. All data analysis of calcium and magnesium content for B100 samples produced January-December 2019

Data reported as "greater than X" or "less than X" are assumed to have a value of $X$

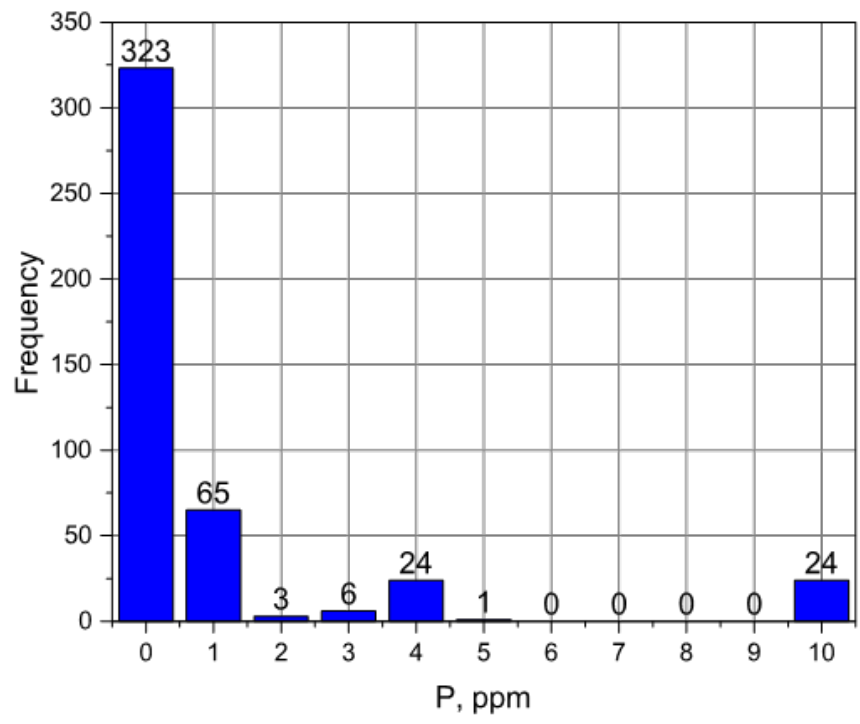

Figure A-3. All data analysis of phosphorus content for B100 samples produced JanuaryDecember 2019

Data reported as "greater than X" or "less than X" are assumed to have a value of $X$ 


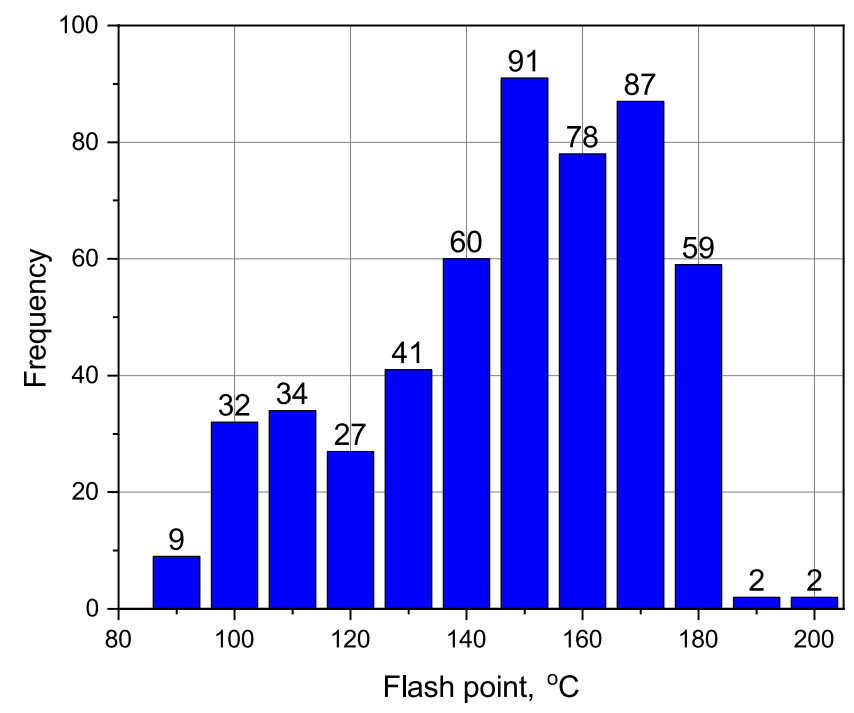

Figure A-4. All data analysis of flash point for B100 samples produced January-December 2019 Data reported as "greater than X" or "less than X" are assumed to have a value of X

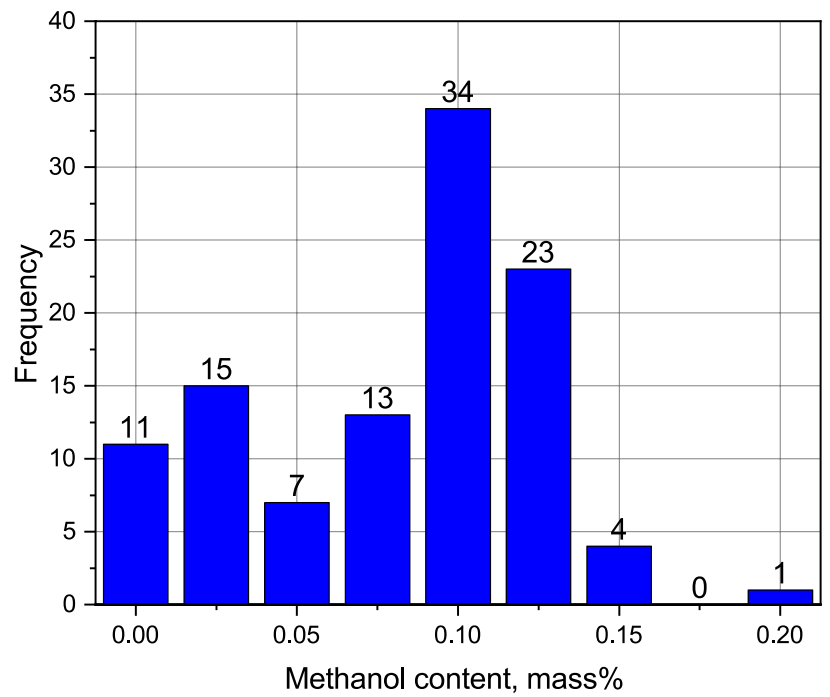

Figure A-5. All data analysis of alcohol control for B100 samples produced January-December 2019

Data reported as "greater than X" or "less than X" are assumed to have a value of $\mathrm{X}$ 


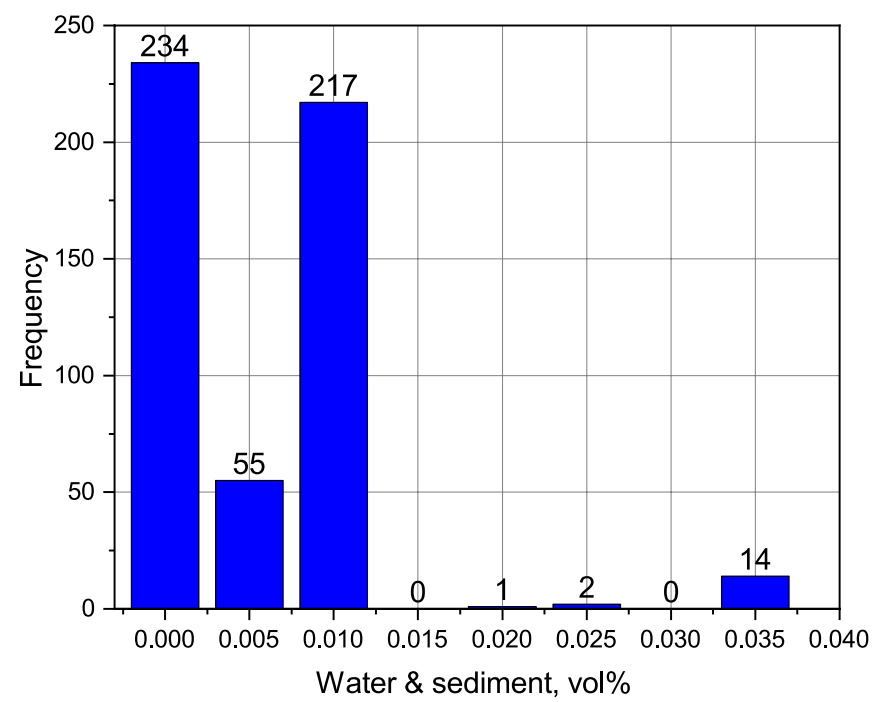

Figure A-6. All data analysis of water and sediment for B100 samples produced JanuaryDecember 2019

Data reported as "greater than X" or "less than X" are assumed to have a value of X

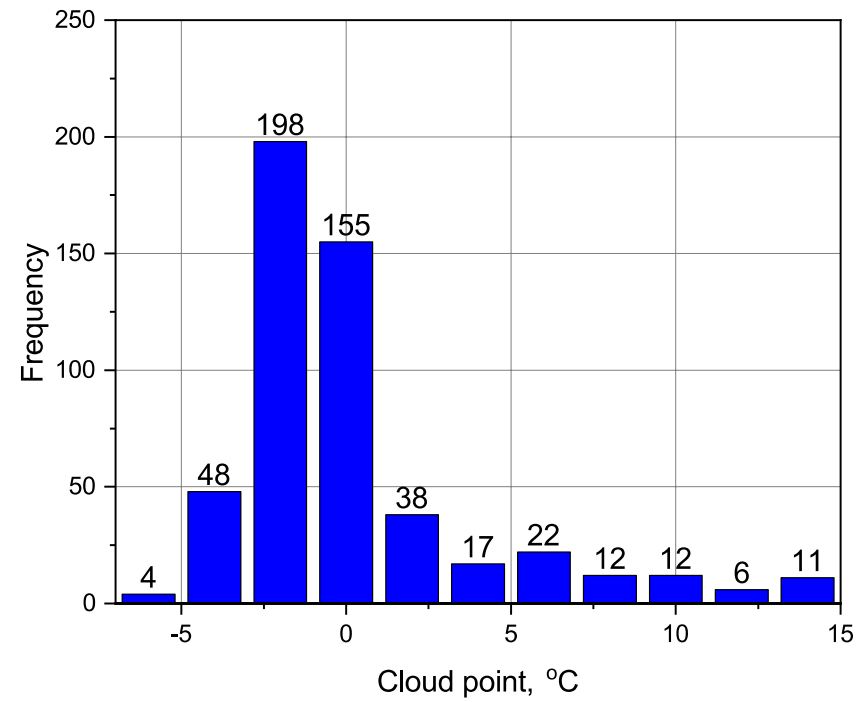

Figure A-7. All data analysis of cloud point for B100 samples produced January-December 2019 Data reported as "greater than X" or "less than X" are assumed to have a value of X 


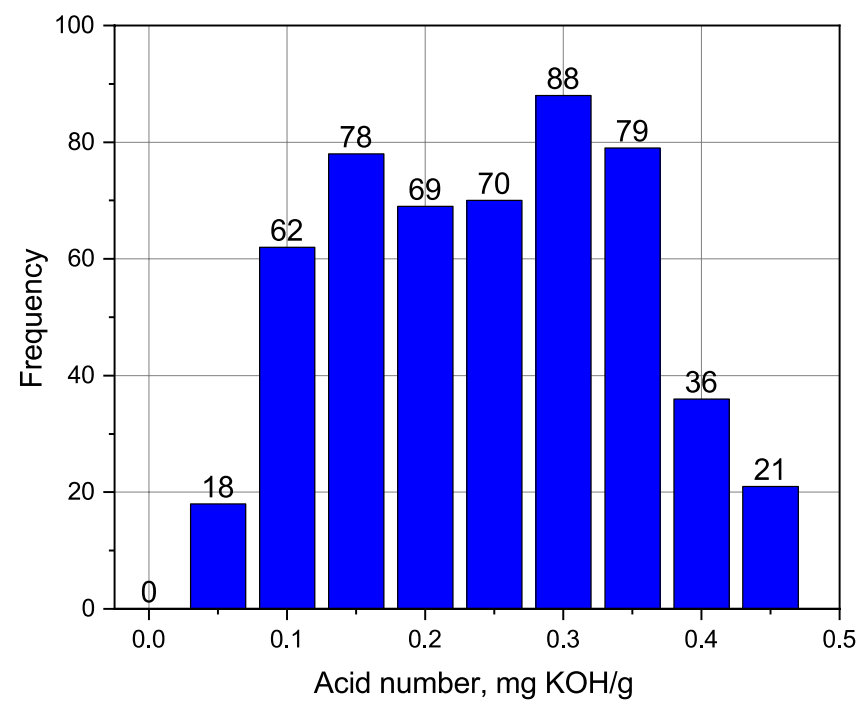

Figure A-8. All data analysis of acid number for B100 samples produced January-December 2019 Data reported as "greater than X" or "less than X" are assumed to have a value of $X$

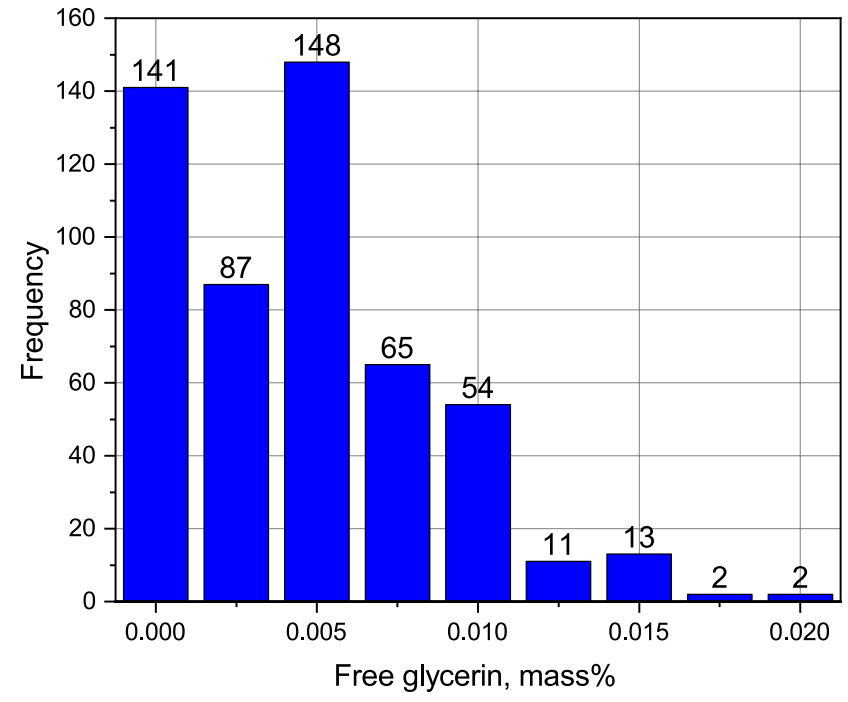

Figure A-9. All data analysis of free glycerin content for B100 samples produced JanuaryDecember 2019

Data reported as "greater than X" or "less than X" are assumed to have a value of X 


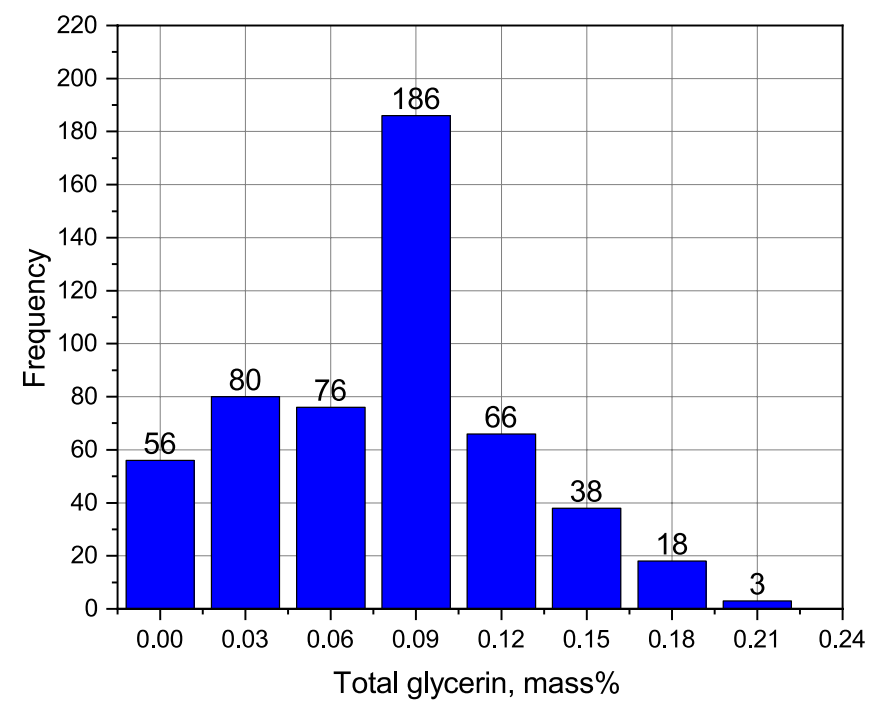

Figure A-10. All data analysis of total glycerin content for B100 samples produced JanuaryDecember 2019

Data reported as "greater than X" or "less than X" are assumed to have a value of X

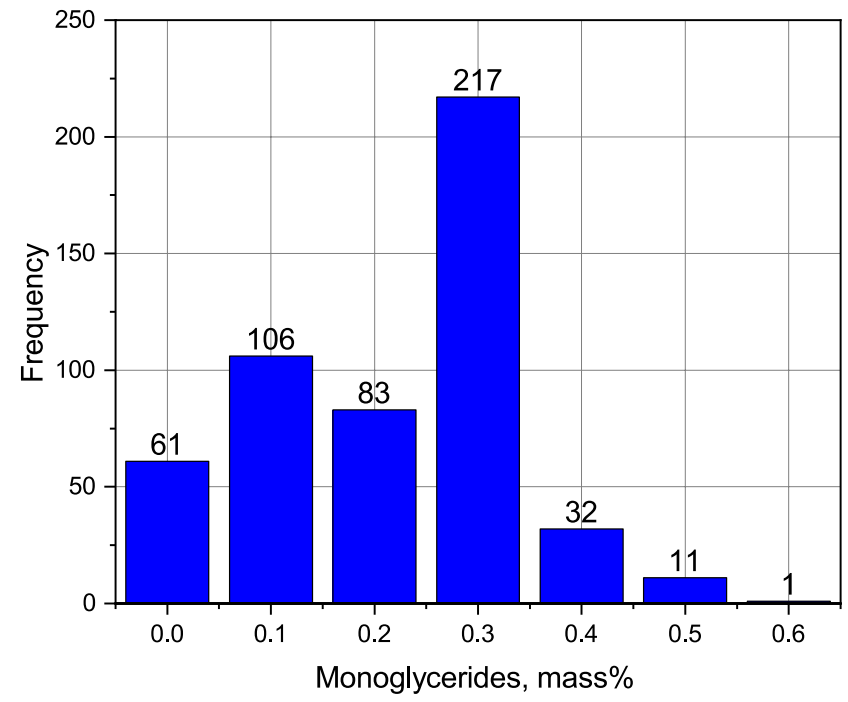

Figure A-11. All data analysis of monoglyceride content for B100 samples produced JanuaryDecember 2019

Data reported as "greater than X" or "less than X" are assumed to have a value of X 


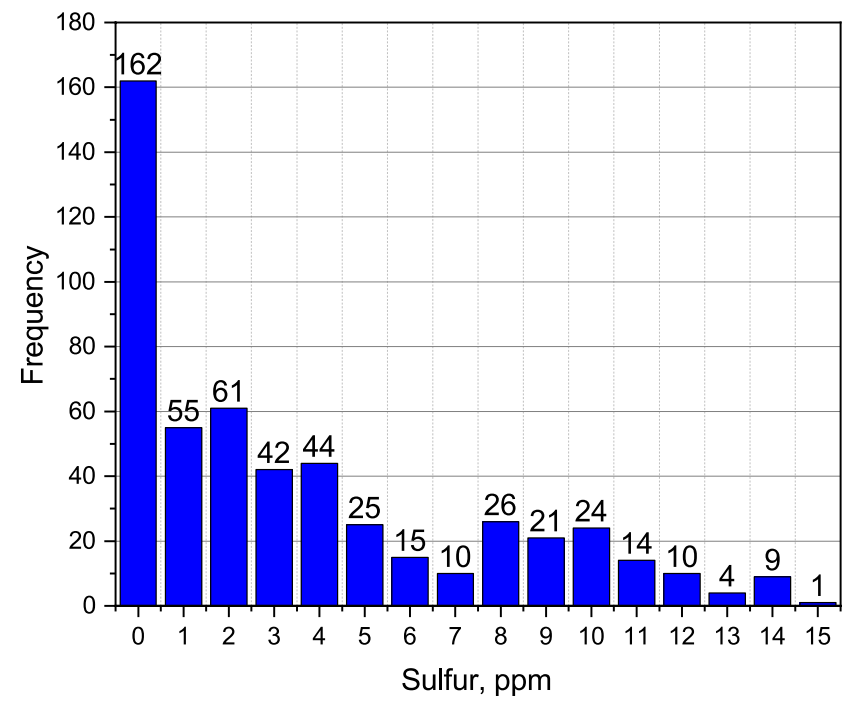

Figure A-12. All data analysis of sulfur content for B100 samples produced January-December 2019

Data reported as "greater than X" or "less than X" are assumed to have a value of $\mathrm{X}$

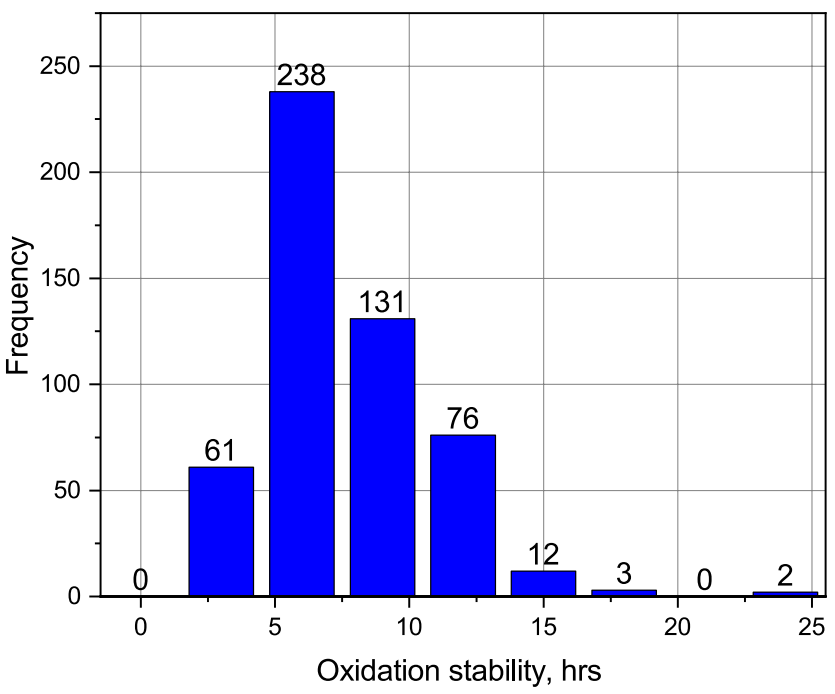

Figure A-13. All data analysis of oxidation stability for B100 samples produced January-December 2019

Data reported as "greater than X" or "less than X" are assumed to have a value of $X$ 


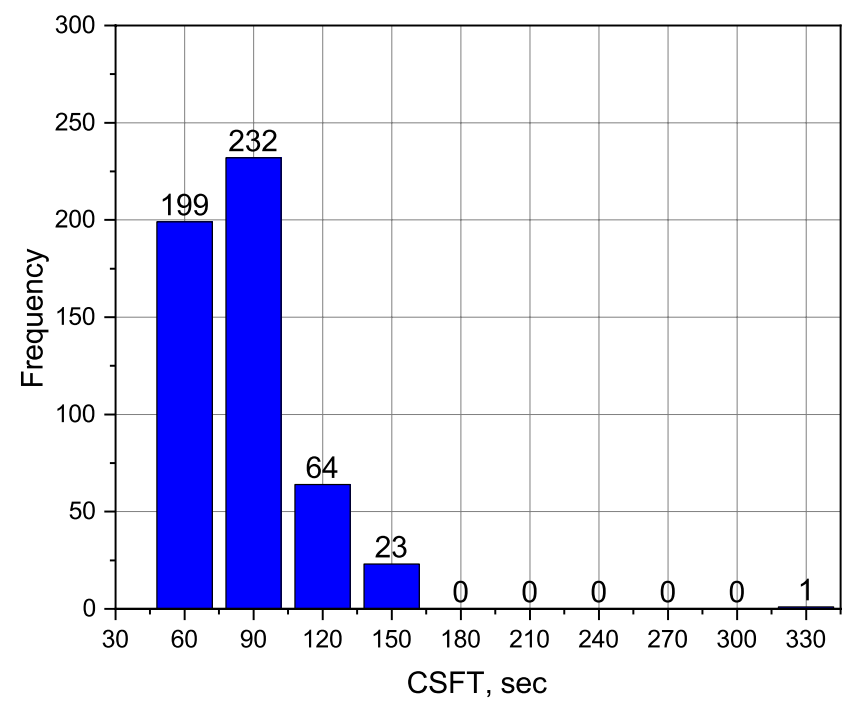

Figure A-14. All data analysis of CSFT for B100 samples produced January-December 2019 Data reported as "greater than X" or "less than X" are assumed to have a value of $X$ 